\title{
Vitamin D and Psychological Status in Dialysis Patient
}

\author{
Kubra Gokalp ${ }^{1(\mathbb{D})}$, Mevra Aydin Ci1 ${ }^{2(\mathbb{D})}$, Aysegul Yayla ${ }^{3(\mathbb{D})}$ \\ ${ }^{1}$ Department of Psychiatric Nursing, Nursing Faculty, Atatürk University, Erzurum, Turkey \\ ${ }^{2}$ Department of Nutrition and Dietetic, Faculty of Health Sciences, Atatürk University, Erzurum, Turkey \\ ${ }^{3}$ Department of Surgery Nursing, Nursing Faculty, Atatürk University, Erzurum, Turkey
}

Copyright@ Author(s) - Available online at https://dergipark.org.tr/en/pub/mbsjohs

Content of this journal is licensed under a Creative Commons Attribution-NonCommercial 4.0 International

License,

Received: 14 July 2021, Accepted: 25 November 2021, Published online: 31 December 2021

(C) Ordu University Institute of Health Sciences, Turkey, 2021

\begin{abstract}
Objective: The study was conducted to determine the association between vitamin D level and psychological status in dialyzed patients.

Methods: The population consisted of dialysis patients in a university hospital dialysis center in Eastern Turkey between March and May 2017. The study's sample involved in 90 dialysis patients (59 hemodialysis, 31 continuous ambulatory peritoneal dialysis). 25(OH) D levels measured in a university hospital. Psychological status was evaluated by Brief Symptom Invantory. Minimum-maximum values, percentage, mean and standard deviation, average, frequency, Kruskal-Walli's test and Pearson's Correlation Analysis were used to evaluate the data.

Results: Mean age was $53.74 \pm 14.83$ years, $61.6 \%$ of patients were female, $38.4 \%$ of patients were male. Mean Vitamin D was $23.51 \pm 29.50 \mathrm{ng} / \mathrm{mL}$. The vitamin D levels of $72.2 \%$ of the patients were below $30 \mathrm{ng} / \mathrm{mL}$. There was statistically significant negative correlation between vitamin $\mathrm{D}$ and somatization, obsessive compulsive disorder, interpersonal sensivity, depression, anxiety, hostility, phobia, paranoid thought, psychotization, other and total scores. Patients who low vitamin D level has had high scores of psychological statuses.

Conclusion: Vitamin D level has effect on psychological status in participants. Vitamin D is essential for psychological wellness in dialysis patients. While clinicians will assess, and therapy of these patient's psychological status should take into account patients's vitamin D status
\end{abstract}

Key words: Medical science, Psychosocial care, Dialysis patient, psychological status

Suggested Citation: Gokalp K, Aydin C1l M, Yayla A. Vitamin D and Psychological Status In Dialysis Patient. Mid Blac Sea Journal of Health Sci, 2021; 7(3): 328-333

\section{Address for correspondence/reprints:}

Kubra Gokalp

Telephone number: +90 (442) 2311448

E-mail: kubragungormus2010@ hotmail.com

Note: *This study was presented as a poster in 39.ESPEN Congress (MON-P133) (https://www.clinicalnutritionjournal.com/action/s howPdf?pii=S0261-5614\%2817\%2930951-2)

Abstract was published in Clinical Nutrution Journal

\section{Introduction}

Chronic Kidney Disease (CKD) is an important public health problem increasingly prevalent in our country as it is in the world. The prevalence of chronic kidney disease in our country was found $15.7 \%$. This means one out of every 6-7 adults has kidney disease (1). When the creatin clearance falls to $12-15 \mathrm{ml} / \mathrm{min}$ in chronic renal disease patients should be initiated replacement therapies such as hemodialysis, peritoneal dialysis, or renal transplantation to maintain survival (2). Hemodialysis and peritoneal dialysis patients constitute $87 \%$ of the patients who receive replacement therapy (1). 
Depression and anxiety are comorbid diseases most associated with end-stage renal disease (3). The prevalence of depression in dialysis patients changes $22.8 \%-39.3 \%$. (4). In particular, depression and anxiety prevalence in hemodialysis patients is up to $70 \%$ (3). Depression episodes increase the pre-existing inflammation in dialysis patients, that is facilitate the occur of other medical problems such as cardiovascular diseases (5). Meanwhile psychological problems may lead to difficulty in compliance with treatment and increase in morbidity and mortality rates (6). Renal $1-\alpha$ hydroxylase activity decreases due to reduction of renal mass in chronic renal failure and as a result, 1-25 hydroxycholecalciferole levels, active vitamin D form, are decreased. (2). The Kidney Dialysis Outcomes Quality Initiative Guidelines are suggested vitamin D supplementation when the 25 hydroxy vitamin D (25 (OH) D) levels are below $30 \mathrm{ng} / \mathrm{ml}$ (7). Vitamin D is important for calcium homeostasis and bone health, also it is essential for brain development and functions. Vitamin D receptors are found in various regions of the brain. One of the regions, where vitamin D receptors are located, is the amygdala where emotions and behaviors are regulated. At the same time, vitamin $\mathrm{D}$ shows neuroprotective effects by regulating calcium concentrations (8). In clinical trials, $25(\mathrm{OH}) \mathrm{D}$ levels were determined to be associated with low cognitive function $(9,10)$, anxiety (11), and depression (9).

In a randomized double-blind study with patients receiving vitamin $\mathrm{D}$ supplementation, in participants with levels of vitamin $\mathrm{D}<40 \mathrm{ng} / \mathrm{dl}$ the Beck Depression Scale (BDI) scores were found higher than levels of vitamin D>40 ng / dl. In addition, improvement in BDI scales was observed in the supplemented group (12). A systematic review of 17 trials in 2013 indicated that depressed patients should be offered daily 1000-2000 IU vitamin D supplementation (12).

In another study, it was determined that CKD patient's vitamin D deficiency was a significant predictor of depression (13). On the other hand, a study conducted in China, vitamin D supplementation in dialysis patients did not have any effect on the symptoms of depression (5).

In the course of dialysis, the nurses are the health workers who most communicate and gives care to patients. Nurses give care according to the requirements of patients which is helping, educating, and raising the quality of life of the patient for improve of their physical and psychological well-being (14). For this reason, it is important that the nurses who are working as a member of the treatment team have an awareness about emphases of vitamin $\mathrm{D}$ when questioning the psychological status and well-being of the patients.

Although the prevalence of serum vitamin D deficiency and depression is high in dialysis patients, there is a limited number of studies on the relationship between vitamin D level and psychological status. The study was planned to determine the relationship between serum vitamin D level and psychological status in patients with dialysis taking into consideration taking into account this shortcoming in the literature.

\section{Methods}

\section{Study Design and Sample}

This descriptive study was completed between March 2017 and May 2017 in a university hospital dialysis center in Eastern Turkey. The population consisted of dialysis patients in a university hospital dialysis center (96 hemodialysis, 52 continuous ambulatory peritoneal dialysis patients). This study sample group consisted of 59 hemodialysis, 31 continuous ambulatory peritoneal dialysis patients who met the inclusion criteria and accepted to participate in the study. Inclusion criteria of the study; 1) Do not use psychiatric or sleeping medicine 2) Being over 18 years of age 3 ) Being dialysis disease at least 6 mounts.

\section{Data Collection Tools}

1. Personal Information Form: The Personal Information Form was involved three questions regarding sociodemographic characteristics of participants.

2. Vitamin D: Patients's serum $25(\mathrm{OH})$ D level was measured by using electrochemiluminescence immunoassay on a Beckman Coulter Autoanalyzer in a university hospital laboratory in Turkey (15)

3. Brief Symptom Inventory (BSI): The BSI was developed by Derogatis and Melisaratos (16) evaluates psychological or psychiatric pathology in person. The inventory is a 53 item and the 5-point Likert scale ("not at all" (0) "a lot" (4)). (16). The Turkish validity reliability study was conducted by Sahin, and Durak (17).

\section{Ethical Considerations}

The Ethics Committee of Faculty of Health Sciences was approved (Decision No:2017/03/09) 
and legal permission. The participants were informed about the purpose and their questions were answered. Since the use of human fact in this study requires protection of individual rights, "Protection of Confidentiality Principle", "Informed Consent Principle" and "Voluntary Basis" and which are relevant ethical principles were realized.

\section{Statistical analysis}

The study to assess the data was used Statistical Package for the Social Sciences (SPSS 22.0. Normal distribution of variables was examined by the Kolmogorov-Smirnov, Shapiro-Wilk tests and normality plots. Descriptive analysis (minimummaximum values percentage, mean and standard deviation, average, frequency) were used to evaluate the data. As well as Kruskal-Wallis test and Pearson's Correlation Analysis were used to analyze relationships among serum vitamin $D$ level and psychological status in participants. The level of significance was set at $\mathrm{p}<0.05$.

\section{Results}

This study was conducted with 90 dialysis patient (59 hemodialysis, 31 continuous ambulatory peritoneal dialysis). Mean age was $53.74 \pm 14.83(18-81)$ years, $61.6 \%$ of patients were female, $38.4 \%$ of patients were male. Mean Vitamin D was $23.51 \pm 29.50 \mathrm{ng} / \mathrm{mL}$ (3-118) (Table 1)

Table 1. Demographic status of patients

\begin{tabular}{|c|c|c|}
\hline Demographic Status $(\mathrm{N}=90)$ & n & $\%$ \\
\hline \multicolumn{3}{|l|}{ Dialysis Type } \\
\hline Hemodialysis & & 65.6 \\
\hline Peritondialysis & 31 & 34.4 \\
\hline Gender & & 61.1 \\
\hline Women & 35 & 38.9 \\
\hline \multicolumn{3}{|l|}{ Man } \\
\hline \multirow[t]{2}{*}{ Age } & & $\operatorname{Min} \pm \operatorname{Max}$ \\
\hline & $53.74 \pm 14.83$ & $18-81$ \\
\hline Vitamin D & $23.51 \pm 29.50$ & $3-118$ \\
\hline
\end{tabular}

M:Mean, Sd:Standart deviation

Table 2. Levels of Vitamin D

\begin{tabular}{lccc}
\hline $\begin{array}{l}\text { Vitamin D } \\
(\mathbf{N = 9 0 )}\end{array}$ & Group & $\mathbf{n}$ & \% \\
\hline $\mathrm{VD}<20 \mathrm{ng} / \mathrm{mL}$ & 57 & 63.3 \\
\hline $\mathrm{VD} 20-30 \mathrm{ng} / \mathrm{mL}$ & 8 & 8.9 \\
\hline $\mathrm{VD}>30 \mathrm{ng} / \mathrm{mL}$ & 25 & 27.8 \\
\hline
\end{tabular}

Table 3. The relationship between patients' Vitamin D levels and BSI score averages

\begin{tabular}{|c|c|c|c|c|c|}
\hline Scale & Vitamin D Grup & $\mathbf{M} \pm \mathbf{S d}$ & & $\mathbf{K W}$ & $\mathbf{p}$ \\
\hline \multirow[t]{3}{*}{ Somatization } & VD <20ng/mL & $8.16 \pm 5.25$ & \multirow[t]{2}{*}{$r=-0.263$} & \multirow[t]{3}{*}{5.141} & \multirow[t]{3}{*}{0.076} \\
\hline & VD 20-30 ng/mL & $7.00 \pm 1.87$ & & & \\
\hline & VD >30 ng/mL & $5.39 \pm 4.47$ & $\mathrm{p}=0.012$ & & \\
\hline \multirow{3}{*}{$\begin{array}{l}\text { Obsessive } \\
\text { compulsive } \\
\text { disorder }\end{array}$} & VD $<20 \mathrm{ng} / \mathrm{mL}$ & $7.55 \pm 3.76$ & \multirow[t]{3}{*}{$\mathrm{r}=-0.378$} & \multirow[t]{3}{*}{11.094} & \multirow[t]{3}{*}{0.004} \\
\hline & VD 20-30 ng/mL & $6.25 \pm 4.46$ & & & \\
\hline & 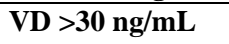 & $4.79 \pm 4.23$ & & & \\
\hline \multirow{3}{*}{$\begin{array}{l}\text { Interpersonal } \\
\text { sensivity }\end{array}$} & VD $<20 \mathrm{ng} / \mathrm{mL}$ & $4.66 \pm 2.99$ & \multirow[t]{3}{*}{$\mathrm{r}=-0.284$} & \multirow[t]{3}{*}{6.855} & \multirow[t]{3}{*}{0.032} \\
\hline & VD 20-30 ng/mL & $4.00 \pm 1.07$ & & & \\
\hline & VD >30 ng/mL & $2.91 \pm 2.48$ & & & \\
\hline \multirow[t]{3}{*}{ Depression } & VD $<20$ ng/mL & $7.28 \pm 4.71$ & \multirow[t]{3}{*}{$\mathrm{r}=-0.330$} & \multirow[t]{3}{*}{9.894} & \multirow[t]{3}{*}{0.007} \\
\hline & VD 20-30 ng/mL & $6.00 \pm 1.60$ & & & \\
\hline & VD >30 ng/mL & $3.87 \pm 2.67$ & & & \\
\hline \multirow[t]{3}{*}{ Anxiety } & VD $<20 \mathrm{ng} / \mathrm{mL}$ & $7,07 \pm 4.77$ & \multirow{3}{*}{$\mathrm{r}=-0.319$} & \multirow[t]{3}{*}{10.709} & \multirow[t]{3}{*}{0.005} \\
\hline & VD 20-30 ng/mL & $4,50 \pm 2.78$ & & & \\
\hline & VD >30 ng/mL & $3.56 \pm 2.65$ & & & \\
\hline \multirow[t]{3}{*}{ Hostility } & VD $<20 \mathrm{ng} / \mathrm{mL}$ & $5.89 \pm 3.97$ & \multirow[t]{3}{*}{$\mathrm{r}=-0.232$} & \multirow[t]{3}{*}{6.873} & \multirow[t]{3}{*}{0.032} \\
\hline & VD 20-30 ng/mL & $3.75 \pm 2.31$ & & & \\
\hline & VD >30 ng/mL & $3.43 \pm 2.51$ & & & \\
\hline \multirow[t]{3}{*}{ Phobia } & VD $<20 \mathrm{ng} / \mathrm{mL}$ & $5.89 \pm 3.97$ & \multirow[t]{3}{*}{$\mathrm{r}=-0.291$} & \multirow[t]{3}{*}{7.057} & \multirow[t]{3}{*}{0.029} \\
\hline & VD 20-30 ng/mL & $3.75 \pm 2.31$ & & & \\
\hline & VD >30 ng/mL & $3.38 \pm 2.43$ & & & \\
\hline \multirow[t]{3}{*}{ Paranoid thought } & VD $<20$ ng/mL & $5.89 \pm 3.97$ & $\mathrm{r}=-0.247$ & 4.790 & 0.091 \\
\hline & VD 20-30 ng/mL & $3.75 \pm 2.32$ & & & \\
\hline & VD >30 ng/mL & $3.85 \pm 2.93$ & $\mathrm{p}=0.019$ & & \\
\hline Psychotization & VD $<20 \mathrm{ng} / \mathrm{mL}$ & $5.89 \pm 3.97$ & $r=-0.248$ & 6.713 & 0.035 \\
\hline & VD 20-30 ng/mL & $3.75 \pm 2.31$ & & & \\
\hline & VD >30 ng/mL & $3.64 \pm 3.20$ & $\mathrm{p}=0.018$ & & \\
\hline Other & VD $<20 \mathrm{ng} / \mathrm{mL}$ & $4.71 \pm 3.17$ & $\mathrm{r}=-0.293$ & 8.485 & 0.014 \\
\hline & VD 20-30 ng/mL & $3.00 \pm 1.85$ & & & \\
\hline & VD >30 ng/mL & $2.58 \pm 3.20$ & $\mathrm{p}=0.005$ & & \\
\hline Total & VD $<20 \mathrm{ng} / \mathrm{mL}$ & $6.01 \pm 35.46$ & $\mathrm{r}=-0.329$ & 8.768 & 0.012 \\
\hline & VD 20-30 ng/mL & $45.75 \pm 17.56$ & & & \\
\hline & VD >30 ng/mL & $37.44 \pm 22.58$ & $\mathrm{p}=0.002$ & & \\
\hline
\end{tabular}


As seen of Table 2, 63.2\% of patients were levels of Vitamin $\mathrm{D}<20 \mathrm{ng} / \mathrm{mL}, 8.9 \%$ of patients were levels of Vitamin D 20-30 ng/mL, \%27.8 of patients were levels of Vitamin D > $30 \mathrm{ng} / \mathrm{mL}$.

According to the Table 3, negatif correlation was found between Vitamin D and psychological status in participants $(p=0.002)$. There was significant relation between Vitamin $\mathrm{D}$ and somatization $(\mathrm{p}=0.012)$, obsessive compulsive disorder $\quad(p=0.000)$, interpersonal sensivity $(\mathrm{p}=0.007), \quad$ depression $\quad(\mathrm{p}=0.001), \quad$ anxiety $(\mathrm{p}=0.002)$, hostility $(\mathrm{p}=0.028)$, phobia $(\mathrm{p}=0.005)$, paranoid thought $(\mathrm{p}=0.019)$, psychotization $(\mathrm{p}=0.018)$ and other $(\mathrm{p}=0.005)$.

Patients who low Vitamin D level has had high scores.

\section{Discussion}

The study was conducted to determine the association between vitamin D level and psychological status in dialyzed patients. To our best knowledge, this study was the first that association between vitamin $\mathrm{D}$ level and psychological status in dialyzed patients in Turkey. End-stage renal failure affects the physical, mental, and social well-being of patients (18). Psychiatric disorders such as depression and anxiety are most commonly comorbid diseases associated with endstage renal disease (3). It has been shown that in a previous study more than $50 \%$ of dialysis patients had depression and depression reduced the quality of life and increased mortality (18).

In the present study, we found a high rate of prevalence of serum vitamin D deficiency. Many factors such as physiological, biochemical, psychosocial, nutrition contribute to the development and progression of depression in dialysis patients (19). It has been showed that vitamin D deficiency, which is frequently seen in dialysis patients, can be one of the causes of depression (5). In parallel with this study, vitamin $\mathrm{D}$ deficiency was determined about $80 \%$ of the dialysis patients (20). In another study, level of vitamin D was condected about $87.1 \%$ of dialysis patients had levels $<30 \mathrm{ng} / \mathrm{ml}(21)$.

In studies of the relationship between vitamin $D$ and depression, low levels of vitamin $\mathrm{D}$ were associated with depression $(22,13)$. In a study about the relationship between depression prevalence and vitamin D levels, the prevalence of depression in individuals with $25(\mathrm{OH}) \mathrm{D}$ level $<30$ $\mathrm{ng} / \mathrm{mL}$ was $22.6 \% ; 25.8 \%$ for $<20 \mathrm{ng} / \mathrm{mL}$ and $35.0 \%$ for $<10 \mathrm{ng} / \mathrm{mL}$ ( 23). Zhang et al. was shown that $44 \%$ of the 484 dialysis patients had depression and the average serum vitamin $\mathrm{D}$ level was $17.6 \pm 7.7 \mathrm{nmol} / \mathrm{L}$. Depressive symptoms were more common in dialysis patients with low $\mathrm{D}$ vitamin levels, but $\mathrm{D}$ vitamin supplementation didn't effect on the psychological status. Researchers have noted that the dose of vitamin D supplementation and follow-up time may be inadequate for the treatment of depression (5). In this study, it was shown that the score of depression was higher in patients with low levels of seum vitamin D. Vitamin D receptors are found in many regions of the brain. It has been suggested that they have many functions in the brain, such as neuroprotection, neuroplasticity, inflammation, and regulation of neurotrophic factors. The presence of vitamin D receptors in dopaminergic cells and vitamin D-responsive elements in promotor regions of tryptophan hydroxylase and serotonin receptor genes that this supports the possible biological association between psychiatric disorders and D vitamin deficiency (24).

In the present study, obsessive compulsive disorder, interpersonal susceptibility, depression, anxiety, hostility, psychoticism and phobia scores were found to be higher in patients with low vitamin D levels. It has been reported that total scores, somatization, obsessive compulsive disorder, interpersonal sensitivity, depression, anxiety, and paranoid thinking scores were similar in dialysis patients whereas hostility, phobic anxiety and psychosis scores were higher in patients with peritoneal dialysis $(25,26)$. Furthermore, depression, anxiety, hostility, and interpersonal susceptibility scores were found to be higher in the dialysis treatment subjects compared to the control group in a study comparing end-stage renal patients receiving without receiving dialysis treatment (27).

In this study, for the first time in the literature, the relationship between serum vitamin D levels and other depressive psychological disorders such as somatization, anxiety, obsessive compulsive disorder, phobia, paranoid thought, psychosis, hostility, interpersonal sensitivity in dialysis patients has been shown.

\section{Conclusion}

Vitamin D level has significant effect on psychological status in dialysis patients. While clinicians will assess, and therapy of dialysis patient's psychological status should take into account patients's vitamin D status and vitamin D may be used to replace or improve the efficacy of medical treatment. For this reason, while health 
professionals' recommendations to patients in this respect, need to have knowledge and awareness about the studies on vitamin $\mathrm{D}$. The results here may provide a basis for future research with regard to evaluating the use of vitamin $\mathrm{D}$ in the management of psychological status of dialysis patients. In this regard, there is need for more randomized controlled trials.

Ethics Committee Approval: The Ethics Committee of Faculty of Health Sciences was approved (2017/03/09) and legal permission.

Peer-review: Externally peer-reviewed.

Author Contributions:

Concept: K.G., M.A.C., A.Y., Design: K.G., M.A.C., A.Y., Literature Search: K.G., M.A.C.,

Data Collection and Processing: K.G., M.A.C., A.Y., Analysis or Interpretation: K.G., Writing: K.G., M.A.C., A.Y.

Conflict of Interest: No conflict of interest was declared by the authors.

Financial Disclosure: The authors declared that this study hasn't received no financial support.

\section{References}

1. Turkey Ministry of Health. Turkey Kidney Diseases Prevention and Control Program, 2018-2023. (cited 2021 Julay 12). Available from:

https://hsgm.saglik.gov.tr/depo/birimler/kronik -hastaliklar-engelli-

db/hastaliklar/bobrek_hastaliklari/kitap_ve_ma kaleler/Turkiye_Bobrek_Hastaliklari_Onleme_ ve_Kontrol_Programi_2018-2023.pdf.

2. Ersoy FF. Renal Osteodistrofi. Turkiye Klinikleri J Orthop \& Traumatol-Special Topics 2010; 3(2): 60-67.

3. Feroze U, Martin D, Reina-Patton A, KalantarZadeh K, Kopple JD. Mental Health, Depression, and Anxiety in Patients on Maintenance Dialysis. Iranian J Kidney Disease.2010; 4(3): 173.

4. King-Wing Ma T, Kam-Tao Li P. Depression in Dialysis Patients. Nephrology 2016; 21(8): 639646.

5. Zhang J, Zhang P, Ni X, Bao B, Huang C, Wu $\mathrm{Y}$, et al. Vitamin D Status in Chronic Dialysis Patients with Depression: A Prospective Study. BMC Psychiatry 2014; 14(1): 125.

6. Oztas P, Seker N, Taskintuna N. Group Therapy in Patients with Chronic Renal Disease. Arch Neuropsychiatry 2012; 49(1):63-68.
7. Uhlig K, Berns JS, Kestenbaum B, Kumar R, Leonard MB, Martin KJ, et al. KDOQI US Commentary on the 2009 KDIGO Clinical Practice Guideline for the Diagnosis, Evaluation, and Treatment of CKD-Mineral and Bone Disorder (CKD-MBD). American J Kidney Disease 2010;55(5): 773-799.

8. Ganji V, Cristiana M, Mildred MC, McCarty F,Wang YT. Serum Vitamin D Concentrations are Related to Depression in Young Adult us Population: The Third National Health and Nutrition Examination Survey. Intern Arch Med 2010;3: 29.

9. Wilkins CH, Sheline YI, Roe CM, Birge SJ, Morris JC. Vitamin D Deficiency is Associated with Low Mood and Worse Cognitive Performance in Older Adults. American J Geriatric Psychiatry 2006;14:1032-40.

10.Przybelski RJ, Binkley NC. Is Vitamin D Important for Preserving Cognition? A Positive Correlation of Serum 25-Hydroxyvitamin D Concentration with Cognitive Function. Arch Biochem Biophy 2007;460(2): 202-205.

11.Armstrong DJ, Meenagh GK, Bickle I, Lee AS, Curran ES, Finch MB. Vitamin D Deficiency is Associated with Anxiety and Depression in Fibromyalgia. Clin Rheumatol 2007;26: 551-4. 12.Jorde R, Sneve M, Figenschau Y, Svartberg J, Waterloo K. Effects of Vitamin D Supplementation on Symptoms of Depression in Overweight and Obese Subjects: Randomized Double Blind Trial. J Internal Med 2008;264: 599-609.

13.Jhee JH, Kim H, Park S, Yun HR, Jung SY, Kee YK, et al. Vitamin D Deficiency is Significantly Associated with Depression in Patients with Chronic Kidney Disease. PloS One 2017;12(2): e0171009.

14.Kara B. Compliance with Treatment in Hemodialysis Patients. Gulhane Med J 2007; 49:132-136.

15.Cankaya E, Bilen Y, Keles M, Uyanık A, Akbas M, Gungor A, et al. Comparison of Serum Vitamin D Levels among Patients with Chronic Kidney Disease, Patients in Dialysis, and Renal Transplant Patients. Transplant Proceed 2015; 47 (5): 1405-1407.

16.Derogatis LR, Melisaratos N. The Brief Symptom Inventory: An Introductory Report. Psychol Med 1983; 13 (3):595-605.

17.Sahin N, Durak A. Brief Symptom Inventory: Adaptation for the Turkish Youth. Turkish J Psychol 1994; 9:44-56. 
18. Nabolsi MM, Wardam L, Al-Halabi JO. Quality of Life, Depression, Adherence to Treatment and Illness Perception of Patients on Hemodialysis. Intern $\mathbf{J}$ Nursing Practice 2015;21(1):1-10.

19.Chan R, Steel Z, Brooks R, Heung T, Erlich J, Chow J, et al. Psychosocial Risk and Protective Factors for Depression in the Dialysis Population: A Systematic Review and MetaRegression Analysis. J Psychosom Res 2011; 71(5): 300-310.

20.Bhan I, Burnett-Bowie SAM, Ye J, Tonelli M, Thadhani R. Clinical Measures İdentify Vitamin D Deficiency in Dialysis. Clin J American Soc Nephrol 2010; 5(3): 460-467.

21.Nazzal ZA., Hamdan Z, Natour N, Barbar M, Rimawi R, Salaymeh E. Prevalence of Vitamin D Deficiency among Hemodialysis Patients in Palestine: A Cross-Sectional Study. Intern J Nephrology 2021:1-6.

22. Anglin RE, Samaan Z, Walter SD, McDonald SD. Vitamin D Deficiency and Depression in Adults: Systematic Review and Meta-Analysis. British J Psych 2013;202(2): 100-107.

23.Stewart R, Hirani V. Relationship Between Vitamin D Levels and Depressive Symptoms in Older Residents from a National Survey Population. Psychosom Med 2010; 72: 608612.

24.Callegari ET, Reavley N, Gorelik A, Garland SM, Wark JD. Serum 25-Hydroxyvitamin D and Mental Health in Young Australian Women: Results from the Safe-D Study. J Affective Disorder 2017;224: 48-55.

25.Cinar S, Karaca S, Bahcebasi ZB. Comparison of the Mental Symptoms in Peritoneal Dialysis and Haemodialysis Patients. Acta Medica 2015; 31: 1027.

26.Palmieri GA, de Oliveira Oller A, Serra GA, Palota Eid L, Alcalá Pompeo D, de Lima EQ, et al. Anxious and Depressive Symptoms in Hemodialytic Treatment Patients. J Nursing UFPE 2017; 11(11).

27. Yu HB, Jiang AL, Wei F, Chen HY, Wang LH. Investigation of Mental Health Condition in Patients with Maintenance Dialysis. J Tianjin Med Uni 2009;1: 040.

28.Chatterjee S, Mandal D, Das A, Biswas I, Shil R, Mazumdar P, Maiti N. Endodontic management of open apices by two bioactive materials: A case series. Int J Med Heal Res. 2019;17;5(8):19-22. 